Chitja Twala

Senior Lecturer,

Department of History,

University of the

Free State

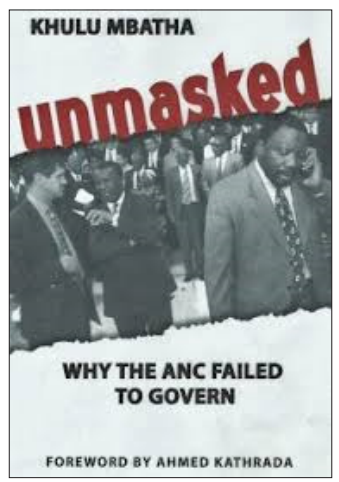

DOI: https://dx.doi. org/10.18820/24150509/

JCH42.v2.11

ISSN 0258-2422 (Print) ISSN 2415-0509 (Online)

Journal for Contemporary History

2017 42(2):227-230

(C) UV/UFS

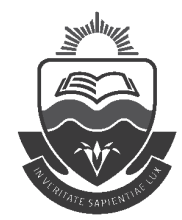

\section{BOOK REVIEW / BOEKBESPREKING}

Khulu Mbatha, Unmasked: Why the ANC failed to govern. Sandton: KMMM Review Publishing Company (Pty) Ltd, 2017. ISBN: 978-0-9922329-7-9, 250 pages.

Khulu Mbatha, the author of this book, has been within the African National Congress (ANC) circles for more than four decades. He has occupied different senior positions within the structures of the organisation, both in exile and inside the country. Although the content of the book is contemporary in nature, it sheds some light on the important evolution of the ANC's history over time. In this book the author asks critical questions pertaining to the preparedness of the ANC to lead. The following questions are pondered and answered by the author: How prepared was this liberation movement to become a democratic government? Did the ANC understand the economy and how to manage it? Did the speed of transition wrong-foot the ANC? Is there still a role for the Tripartite Alliance?

The author challenges the leadership of the ANC in that it has a duty to govern properly and to dispel perceptions that African liberation movements cum ruling parties, are inherently corrupt. The book is not academic or scholarly, but the author successfully reflects on the history of the ANC and provides inside knowledge thereof. Therefore, the author tells the story from an insider's perspective. Furthermore, although with little success, the author tries to "detach" himself from being part of the history of the ANC to become an observer. In the book, Mbatha paints a picture of where the struggle went wrong, and how the past wrongs should be corrected in order to take the ANC forward.

The book is divided into seven uneven chapters. Chapter one is about the exile years of the ANC, with reference to the 1960s, 1970s and 1980s. Because the ANC had to establish itself in foreign territory, the narrative looks at the political foundations of the ANC in exile. The chapter explains the challenges faced by ANC members and leaders in exile. The survival of the ANC depended on the political and economic conditions that prevailed in exile. According to the author, "[t]he membership as a 
whole was dynamic and committed to the course of the struggle for liberation. Almost every cadre and member of the ANC was a political mobiliser and defender of the organisation" (p. 10). In exile, the ANC also experienced some political challenges. For example, dealing with interpersonal relationships between the members of the organisation, and with a leadership creating a onedimensional, glorious, romantic image of the Umkhonto we Sizwe (MK) cadre at the expense of the behavioural challenges experienced in the camps. One other major challenge was to deal with MK cadres who wanted to infiltrate South Africa immediately after receiving military training. In this chapter, the author succeeds in providing a holistic picture of the ANC in exile.

Chapter two traces one of the most important periods in the ANC's history, namely, the negotiations leading up to the 1994 elections. Critical questions are asked in this chapter; for example, was the ANC ready to negotiate? Who stood to gain more from the negotiation process? What was the relevance of the Strategy and Tactics, as well as the Freedom Charter documents in assisting the ANC in positioning itself as the "government in waiting"? Fleshing out the above mentioned questions in more critical ways could help readers in understanding the value of these documents in furthering South Africa's struggle for liberation. In this chapter the author argues that these two documents were instrumental in bringing about a common understanding and interpretation of the struggle against apartheid. According to Mbatha, the issue of negotiations was a giveand-take situation and, therefore, both the ANC and the National Party (NP) had to cooperate with each other for the sake of progress (p. 65). He laments the extent to which the ANC had to compromise; something that later had a negative impact on the future prospects of the Party. Although this chapter is readerfriendly, one criticism is that, to a certain extent, the author presents his side of the story only, without really objectively providing other sides to his observations and experiences as highlighted in the chapter. In most cases, the sources used simply corroborate his side of the story. Furthermore, the chapter is littered with direct quotations with little interpretation of the findings.

Chapter three deals with the transition period between 1991 and 1994. It examines the first two national conferences held by the ANC after being unbanned. The first conference was held in Durban in July 1991 and the second one in Bloemfontein in December 1994. These conferences provided evidence indicating that the ANC was undergoing a vigorous change. In this chapter the author excellently traces the fragmented nature of the ANC membership after it was unbanned. Here, reference is made to the members and leaders who were on Robben Island in exile and those who operated aboveground in the ANCaligned structures. One other aspect addressed in this chapter is the question of the generation gap amongst the members of the ANC and the leadership. The latter posed serious challenges in the quest for unity within the organisation. The 1991 conference also had to deal with, amongst others, issues relating 
to organisational matters, strategy and international relations, consolidation of organisational structures, and dealing with underground structures and MK matters (p. 88).

Chapter four looks at the ideologies that influenced the ANC. Although this is a short chapter, the author succeeds in tracing the past ideologies of the ANC and their evolvement over time. Interestingly, in the first few sentences in the chapter's introduction the author asks and confirms that the ANC had an ideological stance which initially was aligned to African nationalism. This was well captured by Nelson Mandela during the Rivonia Trial when stating, "from its inception the ANC was formed and built up, not as a political party with one school of political thought, but as a parliament of the African people, accommodating people of various political convictions, all united by the common goal of national liberation" (p. 105). Later, as the governing party in South Africa, the ANC had to embrace other ideologies. The author criticises the fact that the National Democratic Revolution (NDR), in one way or another, undermined the political freedom and democracy established. He also alludes to Mandela's 1994 warning about a parasitic class in the ANC which had just emerged. According to the author, the ANC failed to deal with these parasitic members in its leadership ranks.

Chapter five scrutinises the ANC's readiness to govern. It addresses the post-1994 period. In this chapter the author disentangles the complex socioeconomic relationships and the new conditions of democracy in South Africa. Mbatha contends that, although at face value the ANC declared itself to be ready to govern, in practical terms it misjudged the mammoth task which lay ahead. A major challenge highlighted by the author was the issue of cadre deployment. Initially, the ANC did not have a plan for the question of cadre deployment. When it embarked on this process, there was no vetting process to ensure it. When the challenges were identified, the author argues that the ANC took time to address them. The ever-changing nature of the ANC is criticised when the author states that, "the ANC is a liberation movement when it suits it, and a ruling party when this serves its purpose" (p. 121). One may argue against the above observation in the sense that the ANC wanted to advance its policies on governance; therefore, cadre deployment became relevant and significant. The author is commended for the pictures/photos inserted in this chapter. However, the relevance of some of the pictures/photos in this chapter is questionable, because the chapter's title is about post-1994 and some pictures/ photos date as far back as 1990.

Chapter six is the longest. Here, the author identifies six impediments to nation building and social cohesion. Furthermore, the chapter discusses the relevance or irrelevance of the Freedom Charter; the lack of a clear strategy in the ANC to deal with the economy; the perpetual existence of the Tripartite Alliance; the NDR; racism; and the slow process of reconciliation. On the 
question of the Freedom Charter, the author has a problem with the different interpretations attached to the Charter. This, in essence, divides the members of the ANC. In this chapter the author takes the reader back to the banning of the ANC and the vacuum created by this step. The main concern regarding this chapter is the challenge of chronology and the sequencing of events. This compromises the whole question of possible periodisation. The author tries to cluster many different topics and sub-headings into this one chapter.

Chapter seven is a concluding one. It deals with the future prospects of the ANC and how the organisation can resolve the impediments highlighted in chapter six. He suggests the following for the ANC: realignment of forces for positive change in South Africa; a decision by the ANC whether it is a governing party or a ruling party; the necessity of deliberative democracy; and the need for the ANC's Constitution to change.

This book clearly articulates the observations and thoughts of, perhaps, an aggrieved stalwart of the ANC due to the political circumstances prevailing within the organisation at the time of writing. Except for a few typographical corrections and missing words, the book is recommended, since it provides insight into the ANC and its activities in the past and up to about a year ago (2016). 